\title{
MXIT: Uses, Perceptions and Self-justifications
}

\author{
Wallace Chigona, Agnes Chigona, \\ Bomkazi Ngqokelela, and Sicelo Mpofu \\ Department of Information Systems, University of Cape Town \\ Cape Town, South Africa
}

\author{
Wallace.chigona@uct.ac.za; a.chigona@uct.ac.za; \\ bomkazi@gmail.com; sicelo.mpofu@hotmail.com
}

\begin{abstract}
This paper reports on a pilot study investigating the perceptions and use of Mobile Instant Messaging (MIM) amongst the youth in South Africa. MIMs are enjoying a high adoption rate amongst the youth in South Africa and MXit is by far the most popular MIM. However, the media, parents and educators are overly concerned with the use of the system. The accusations against MXit have included the allegations that it is time-wasting for the youth, it is a hunting ground for paedophiles, and it leads to anti-social behaviours. It is interesting, however, that despite the negative perceptions of the system, the youth are still using it, and presumably with their parents' blessings.

Data for the study was gathered through in-depth interviews with randomly selected youth who use MXit, as well as with parents of children who use the system. The study has found that the youth use the system mainly for social networking and that, to most users, the system is more than just a communication tool - it is also part of their lives. The study has also unearthed the perceptions of the users towards fellow users and towards non-users. In addition, it has been noted that both the users and parents of users are employing self-justification strategies to deal with the cognitive dissonance arising from the negative discourse on MXit and their continued use or support of the system. The findings of this study contribute to the understanding of how the youth use new media. The findings could be useful for those who may want to use new media for educating the youth and for marketing purposes.
\end{abstract}

Keywords: Mobile Instant Messaging, MXit, Self justification, South Africa, Youth

\section{Introduction}

Social Interaction Technologies (SITs) have expanded the ways in which people communicate. They have added methods of social networking (Valenzuela, Park, \& Lee, 2008). According to Mitrano (2006, p. 17), the technology offers people the opportunity to burst out of their parochial

Material published as part of this publication, either on-line or in print, is copyrighted by the Informing Science Institute. Permission to make digital or paper copy of part or all of these works for personal or classroom use is granted without fee provided that the copies are not made or distributed for profit or commercial advantage AND that copies 1) bear this notice in full and 2) give the full citation on the first page. It is permissible to abstract these works so long as credit is given. To copy in all other cases or to republish or to post on a server or to redistribute to lists requires specific permission and payment of a fee. Contact 0HPublisher@InformingScience.org to request redistribution permission. communities and make connections around the world. Basket-weavers and metallurgists and other hobby-seekers expanded their expertise, interests, and sometimes even professions, while everything from dating sites to interest groups to social and political movements blossomed. In regions with low Internet and computer penetration - such as South Africa - mobile platforms provide SIT applications (Chigona, 
Kamkwenda, \& Manjoo, 2008). One example of mobile-based SITs is Mobile Instant Messaging (MIM).

The most popular MIM in South Africa (SA) is MXit (Bosch, 2008). Since its inception in 2005, the adoption of the system has been phenomenal (Duarando, Parker, \& de la Harpe, 2007). Currently there are over seven million MXit users and the numbers are growing at the rate of over 9,000 per day. As is the case with computer-based instant messaging applications, the adoption of MXit is particularly high amongst the youth (Durando et al., 2007). However, the wide spread of the system has raised a number of concerns amongst many members of society. The local media points out that inter alia the system has the potential of degrading the moral standards and providing a hunting ground for paedophiles (Chigona \& Chigona, 2008). As Chigona and Chigona (2008) note, the media have mainly based their reports on the stories told by parents and educators and not from the youth who are the main users of the system. While the motivation for the distortion is subject to debate, one can still argue that such negative discourse has the potential of affecting the usage of the system (Cukier, Ngwenyama, Bauer, \& Middleton, 2009; Fairclough, 1995; Jensen \& Jankowsk, 1991). However, that seems not to be the case. It is interesting, therefore, to explore not only the perceptions and the experiences of the users of MXit, but also how the users deal with the negative discourse about the system. Chigona, Kamkwenda, and Manjoo (2008) noted that in most cases parents are responsible for the acquisition of mobile phones as well as for paying the phone bills for the children. It is therefore interesting to investigate how the parents reconcile the negative discourse with their children's use of MXit. An understanding of the users' experiences and perception would help various stakeholders, including the youth, to make the most of the technology.

The aim of this pilot study is to explore the perceptions and use of MXit amongst the South African youth, as well as the perceptions of their parents and how they (both the users and the parents) reconcile the negative discourse, on the one hand, with the use of the system, on the other hand. Data for the study was gathered from the youth who use MXit, as well as from parents of children who use the system. This study contributes towards the understanding of the role of new media in the lives of the youth. MXit has already proved to be a viable teaching/tutoring option as well as a marketing tool (Butegreit, 2007; Duarando et al., 2007). This is especially critical taking into account the low computer and traditional Internet penetration in South Africa. The study also contributes towards the body of knowledge on mobile applications in developing countries. Currently there is a void in research that directly addresses MIM and its social impact in developing countries.

\section{Literature Review}

\section{MXit}

MIM is a synchronous communication tool that works on mobile devices such as PDAs and cell phones. Unlike SMS, MIM uses internet protocol to exchange messages. MIMs function in a way similar to computer-based instant messages (e.g., Messenger and ICQ). Unlike the other MIMs on the South African market, MXit is network-independent i.e. it can operate between interactants on any network provider and the interactants do not have to be on the same network. In contrast, some MIMs (such as noknok and meep) may be used only by interactants on the same network. Some South African youth also use other international MIMs, such as mig33 and Fling (Chigona et al., 2008).

MXit users are able to chat either in chatrooms or on a one-to-one basis with contacts who have been added to their contact lists; there is virtually no limit to the number of contacts one may have. Contacts are added at the discretion of the users. To add a person to the contact list, the ini- 
tiator sends an invitation which the other party must accept. To participate in a chatroom, one needs to subscribe to the chatroom; there is a fee involved. Chatrooms are often centred on a theme (e.g., teens) or around a geographical location (e.g., Cape Town chatroom). Users in chatrooms often use pseudo names and the phone numbers of the guests are not displayed. However, according to media reports, some users opt to or are tricked into revealing their identities in chatrooms. A recently added mode of chatting on MXit is known as MultiMix. In MultiMix a user may invite multiple friends to chat together; the friends don't necessarily have to be on each other's contact list.

One of the factors that has been attributed to the fast growth of MXit is the cost. Unlike sending SMSes, MXit is charged based on the data which is transferred. A MXit message may cost the sender around 2 cents South African, compared to around 70 cents for an SMS message. (Note: 1 cent South African is equivalent to 0.1 cents US).

Due to the nascency of MXit, research specifically on the system is limited. In a study focusing on uses and gratification of mobile Internet amongst South African university students, Chigona and colleagues (2008) note that chatting was the main motivation for using mobile Internet amongst the students, and MXit was the main system they used for chatting. From a sample of school-going youth, Francke and Weidenman (2007) note that the users of the system are generally young and that there is no significant difference in usage across gender. Dourando and colleagues (2007) note that MXit can be useful as a teaching channel. In addition, Butgreit (2007) demonstrated that the system is used for tutoring mathematics to school-going youth. Bosch (2008) focused on how girls used MXit to create a gendered-based as well as a racial-based identity. Investigating the media discourse on MXit, Chigona and Chigona (2008) have established that the media discourse on the system are mainly negative; in the case of parents and educators, the negative sentiments could be partly due to a lack of understanding of the system.

\section{Social Interaction Technologies}

Most studies on SITs have focused on how the technology creates and sustains social networks. Some studies have shown SITs to have the overall benefit of assisting people in creating and maintaining relationships. In contrast, some studies have shown SITs to have the effect of reducing the quality of relationships and, consequently, have an overall negative impact on society. Kraut and colleagues (2002) have detailed the positive and negative effects of SITs on human psychology, behaviour, and social involvement. The authors posit that the Internet has the benefit of expanding the avenues available to users to communicate with families and friends. It has also been claimed that the Internet allows for communication with distant family members and friends for whom alternative means of communication would be difficult or expensive (Kraut et al., 2002; Petersen, 2008). This helps in maintaining or strengthening existing relationships.

Other studies have gone further to analyse the impact of Computer Mediated Communication on the quality of the relationships. Kraut and colleagues (2002) show that the use of the Internet for communication adds value to the quality of personal relationships. McKenna and colleagues (2002) note that in contrast to their counterparts who met face-to-face (F2F), youth who met online were more likely to have longer-lasting relationships. McKenna, Green, and Gleason (2002) attributed this to the fact that the anonymity of Internet interactions reduces the risks of disclosure of personal information that may lead to ridicule or outright rejection. Online relationships also allow users to hide emotional reactions which may otherwise receive disapproval from online peers. Petersen (2008) noted that South African Facebook users use the system to "freeze friendships" - keep in touch with people they are not so keen to be in touch with but at the same time do not want to lose as friends. Such relationships could be acquaintances from the past. 
On a similar note, Flanagin (2005) shows that Instant Messaging is used to express affection, to be fashionable, and for entertainment, relaxation, and sociability. Nevertheless, Takahashi (2008) argues that "for girls, social networking sites are primarily places to reinforce ... friendship; for boys the network also provides opportunities for flirting and making new friends" (p. 20). Bosch (2008) points out that the social networks offer the youth (especially girls) a safe haven to experiment with their sexuality. Ito (2005) shows that the mobile phone has helped to overcome the power geometry of space, allowing adolescents to communicate with friends without parental surveillance. Similarly, others have argued that social network sites have "made the world smaller" as such individuals can exist and operate in non-spatial locations (Lull, 2000; Morley \& Robbins, 1996).

Some studies have shown that SITs have a negative effect on social skills and social relationships. For example, some studies have shown that the use of the Internet and SITs draws users away from real physical interactions that they had possessed with their family members or with their close friends and acquaintances (Kraut et al., 2002; McKenna et al., 2002; Riva \& Galimberti, 1998). Kraut and colleagues (2002) further argue that the benefits of online interactions generally are short-lived; after a period averaging about two to three years, users generally became depressed, lonely, and less socially interactive.

SITs have also been blamed for encouraging or at least enabling lying behaviour, such as forwarding false information about someone or something. Hancock, Thom-Santelli, and Ritchie (2004) suggest that the use of SITs and social networking technologies make it easier for, and tend to encourage, users to engage in lying behaviour. However, the study found that, unlike other forms of SITs, instant messaging did not result in significant change in lying behaviour as compared to F2F communication.

Previous studies have also shown that, with an introduction of any new technology, usually moral panics and public anxieties initially emerge about unforeseen negative consequences of the technology on children (Buckingham, 1993; Valenzuela et al., 2008). As Furedi (1994) puts it, moral panics have a tendency to occur "at times when society has not been able to adapt to dramatic changes" and when these changes lead those concerned to express fear over what they see as a loss of control (p. 3). Chigona and Chigona (2008) point out that concerns and general negativity expressed in media reports on MXit could be a sign of moral panics.

\section{Methodology}

The study was a pilot investigation aimed at raising issues that may be investigated in depth in subsequent studies. Due to its exploratory nature, the study was conducted using a qualitative approach. Empirical data for the study was gathered using one-on-one interviews.

\section{Sampling}

The target population for the study were young (school going age) MXit users as well as parents of young MXit users. Since the majority of the users of the system are high school learners (Bosch, 2008), they (the high school learners) would have been the ideal sample for the study. However, for convenience, the sample was randomly drawn from students who had recently joined university from high school. The sample was limited to twelve MXit users and nine parents. The selected users were drawn from different faculties and varied across demographic factors such as ethnicity and gender. The purpose of this was to ensure a variety in responses and also to reduce any biases that may have resulted. The parents also varied in terms of ethnicity and gender. The sample size of both the users and of parents is too small to warrant broad generalisation of our findings; however, it is adequate for a pilot study. 


\section{Data Collection and Analysis}

All the interviews were audio-recorded and then transcribed. The transcription process helped us to get close to the data - we were able to reflect not only on what the respondents said but also how it was said. We read each typed transcript several times while listening to the corresponding audio tape to ensure accuracy of the transcription and to come to a better understanding of each participant's experiences. The process of transcribing and listening also prompted additional questions for subsequent sets of interviews.

We used Van Manen's (1990) "highlighting" approach to uncover the thematic aspects of the respondents' social experiences. In this approach, we read the text several times. Statements in the text that appeared to be revealing about the phenomenon were highlighted. Themes were identified by highlighting material in the interview transcripts that spoke to the users' experiences. Then we selected each of these highlighted phrases or sentences and tried to ascertain what meaning was put forward in the highlighted material. After identifying the themes, we embarked on the process of recording the themes and describing how they were interrelated. Rewriting continued until we felt that the themes and the relationship between the themes were identified as accurately as possible.

\section{Trustworthiness}

In order to establish trustworthiness, six randomly picked interview transcripts were returned to the respective respondents. The respondents were then asked to verify if that was really how they had responded to the respective questions. Most of the respondents adhered to what they had said during the interviews. The few respondents who wished to change their responses did so, but the changes were regarding syntax and the choice of words used. In addition, coding of the raw data was done independently by two coders. Initial discrepancies in codes prompted additional work that resulted in $90 \%$ of inter-coder agreement. Miles and Huberman (1994) point out that while check-coding aids definitional clarity, it is also a good reliability check. Caution was also taken to make sure that participants were those who were knowledgeable and were close to MXit users' experiences, the events, actions, processes, and settings. This idea echoes Miles and Huberman (1994) when they posit that data from some informants is "better" than others, especially when the informants know the situation very well or have experienced it.

\section{Ethical Considerations}

All interviews were conducted with the full consent of the participants. A cover letter was emailed to all participants explaining the aim of the study and how the interview would be conducted. All interviews were conducted in a private environment without external monitoring. Interviewees were given the option to not answer any questions with which they felt uncomfortable. Privacy and confidentiality concerns were given the deserved consideration (Cohen \& Manion, 1994). We were sensitive not only to how the information was to be protected from unauthorised observation, but also how, if necessary, the participants were to be notified of any unforeseen findings from the research that they may or may not have known. The ethical principle refers to the obligation on our part as the researchers to respect each participant as a person capable of making an informed decision regarding participation in the research study.

\section{Findings}

The analysis of the data yielded the following themes:

- the profile of contacts for the MXit users;

- uses of MXit;

- the role of MXit in the lives of the youth; 
- MXit and user behaviour; and

- perceptions of MXit and its users.

These themes are discussed in the subsequent subsections.

\section{The Profile of Contact Lists}

The respondent youth in our sample had an average of 40 contacts each; in most cases around half of the contacts were invited by the respondents and half invited the respondents. The MXit users' respondents were asked to describe:

1. How they decided who to invite as their contacts, and

2. The criterion used to accept invitations from other MXit users.

Most respondents indicated that they invited and accepted invitations only from people whom they knew personally. One respondent said:

I used to accept some of the people that I chatted with in chatrooms, but when I came to varsity I deleted all of those people and I only invite and accept invitations from people that I know. I don't have anyone on my MXit that I've never met at all. It's like, if I don't know their face or their surname type thing, I don't have them on my MXit.

The respondent added that the people she invited are "those she particularly wished to stay in contact with," whereas the people that invited her might be people who "just wanted to increase the number of contacts they have on MXit." Some of the respondents indicated that some of the people who invited them were "just friends of ... friends"; and some found it difficult to turn down invitations from acquaintances since they "find it awkward." Some indicated that they accepted invitations from people they are not familiar with on a "trial basis." They then interrogate them to see if they could really become friends.

Almost all male users in our sample indicated that they accepted all invitations, while most girls said they accepted only those they knew and liked. In view of media reports that suggest that more girls than boys are victimised through MXit, it is surprising that girls would be more wary than boys when accepting invitations. Our findings also differ from Bosch $(2008$, p. 16) when she indicated that "despite the critiques of lurking sexual predators on MXit ... and reports of potential abuse, girls allocated their cellphones an 'independence-giving' role, allowing for safe experimentation with regard to sexual activity." The difference between our findings and Bosch's could be attributed to the maturity levels of the respondents; our sample was drawn from students who had completed High School while Bosch's respondents were still in High School.

The finding that people use MXit to contact those who are already close to them is interesting, since it differs with the findings of Peterson (2008) about the profile of contacts of South African Facebook users. Peterson notes that people used Facebook to contact people who they were not close to and with whom they would not otherwise make an effort to keep in touch. The difference could be due to the difference in the synchronicity of the two systems. Facebook is asynchronous and, therefore, often used for communication that does not require urgent responses; on the other hand MXit, being synchronous, is ideal for communication requiring urgent response. As Peterson (2008) notes, the need for urgent response to messages is generally positively correlated with the closeness of the interactants. The other reason that MXit is used to communicate amongst people who are close to each other is because one needs the phone number of the person in order to invite them as a friend. In contrast, Facebook contact does not require any contact details that may be presumed personal. 


\section{Uses of MXit}

Most youth from our sample used MXit mainly for social networking. The system allowed the youth to sustain and/or nurture networks of friends and associates. All the youth respondents indicated that the use of MXit enabled them to increase their social connections since it allowed them to "spend more time ... chatting to [friends]" and therefore get "a bit closer to the [friends].”

Most respondents said if they log on and find people who they are not close with, they do not mind chatting with them. Hence, it could be argued that MXit may serve to build relationships. The finding concurs with findings of Nakajima et al. (1999, as cited by Takahashi, 2008) on the use of mobile phones by young people, which concluded that the technology aids the creation of "full-time intimate community" among users.

The youth used the system to gossip with friends. However, different from Bosch (2008), we found no significant difference between boys' and girls' use of MXit for gossiping. Gossiping is a significant kind of communication because it could be an information carrier to sustain the idea of social fellowship without a defined content (Johnsen, 2003). Takahashi $(2008$, p. 9) found that the most common reasons for using Mixi (a Japanese social interaction system) were information exchange and gaining information. These reasons are also clear in our study. For instance, one user respondent said:

Like we get to talk everyday, so you get to find out knew things from the person like how was your day, this and this and that, the next day it's another thing, so you get to find out everyday. Unlike talking to a friend of mine who does not chat on MXit, right? I'll talk to them today, and then I'll talk to them in like five days and then within those days of not talking you'll miss like a lot of things. If I talk to a person everyday it's like ... you get to know that person more and more, it becomes stronger.

MXit users also indicated that they used the application as an antidote to boredom. This use of the system is consistent with findings on the use of similar technologies, e.g., the Takahashi (2008, p. 20) survey which concluded that the most important use of mobile Mixi among the youth was to "kill time or become refreshed". In South Africa, Bosch (2008) found similar results in her study about adolescent girls' use of mobile phones, in particular MXit.

The youth respondents also indicated that they used the system for other instrumental as well as hedonic purposes. Such uses included event planning, downloading and playing games, and checking information about events such as "what's happening in the cinema."

Most of our youth respondents indicated that they chatted only one-to-one and did not use chatrooms. Some considered chatrooms "weird since you chat with people you don't know." One respondent said, "I don't like the whole chatroom thing; I think it's actually really stupid ..." Instead of chatrooms, one respondent indicated that she used MultiMix. The lack of interest in chatrooms is interesting since it contradicts what is mainly portrayed in the media. Most of the negative media reports are based on activities related to chatrooms.

\section{The Role of MXit in the Youth's Lives}

Analysis of the data shows that it was likely that MXit was not just simply a mobile system but part of the youth's lives. The youth's references to MXit showed how the system had to some extent become part of their routines. Some respondents indicated an element of dependency and high levels of commitment to MXit. 
I sort of need MXit because my closest friends and family are at home and I'm in student hostels. So I'm used to chatting to them and exchanging stories every day. So that would be a bit difficult if I didn't have the phone

... I'm so used to it ... when [I] take out my phone, the first thing I do is check who is on MXit. So, like, probably, like when I get used to it, like, 'Okay, let me just lay back on the MXit thing.'

From the extracts, it is likely that for some users, MXit is not merely a communication tool that is used when necessary. It seems MXit plays a big role in the social lives of the youth. At the same time, the mobile phone has taken away the spatial boundary of the home. As one respondent indicated, "I use it, whenever I can get time. I don't really have a set time. I can use it as I'm walking to class." The finding concurs with Takahashi (2008) who found that the youth's use of Mixi is ritualistic as well as instrumental - a natural part of their daily rhythm and something that contributes to their daily lives.

\section{Antisocial Behaviour}

Most of the youth in our sample considered the ownership and use of their mobile phones as giving a sense of freedom, and as such they can use their phones as they like. Some respondents indicated antisocial behaviour on MXit. For instance, one respondent narrated a case of "a parent hooking up with his own daughter on MXit." Such negative behaviours are commonly reported in the media (Chigona \& Chigona, 2008). Two respondents admitted their involvement in some antisocial behaviour:

I go into a chatroom just because my cousins and I, we all go together into the chatroom and cause havoc!

... I used to just say random things, swear, you know, do random stuff that made me laugh or whatever.

Another respondent who uses MXit chatrooms agreed that numerous instances of asocial behaviours are manifested in the chatrooms.

\section{Users' Perceptions of MXit: Its Users and Non-Users}

The analysis shows that the way MXit users perceive the system differs from how their parents as well as non-users view the system and its users. This is in line with other studies (Lemish \& Cohen, 2005; Perloff, 2002) which show that the perceptions about a technology differ between users and other people. These different perceptions are discussed in the subsequent sub-sections.

MXit users from our sample reported a positive view of the system and of its users. Most of the users regarded other users as "cool" and "awesome." The users indicated that they liked that identity. What is being manifested here is self-categorisation which, according to Ellemers, Kortekaas, and Ouwerkerk (1999), is the underlying personal perception that an individual holds of the qualities that a particular social group has to offer.

The users were aware that non-users had a negative perception of the use of MXit and of users of MXit. For instance, some youth respondents indicated that many people think that if one is chatting on MXit then he "is talking to strangers" or "looking for girlfriends on the Internet." The MXit users complained that the media is responsible for the negative image of MXit; as a result people perceive MXit users as "terrible" and "horrifying." One MXit user said:

I blame the media ... my parents know nothing about MXit except for what they read in the newspaper and what they watch on television. 
According to the respondents, the negative perceptions are based on the alarming stories that have embraced the sensationalist news headlines, particularly the ones regarding paedophiles luring young girls in chatrooms into giving out their contact information, which eventually lead to kidnappings, rape, and abductions.

Other MXit users were self-critical. Two female MXit users, for instance, thought that if other people found out that they use the system, they would probably perceive them as "quite antisocial" because that is the way they perceived other MXit users. One of the two respondents said, "I know many people who are quite social on MXit, but they're not social in person." In line with the anti-social claim, one respondent said that he found it easier to communicate via MXit than to communicate face to face. Some research concurs with the finding by showing that the use of MIMs makes some individuals more chatty and communicative (Bosch, 2008, p. 16). Similarly, Bonebrake (2002) shows that parties in relationships that are initiated online generally find it easier to find similarities in each other.

Most of the MXit users in our sample believed that MXit could be a waste of time. One respondent said that one can easily become addicted to MXit. "I know friends who could chat almost the whole night." This finding is consistent with Bosch (2008) who points out that the amount of time the youth spend on the system has been an increasing source of concern for parents and teachers. Waste of time is also one the main criticisms the media levels against MXit use (Chigona \& Chigona, 2008).

Most of the male MXit users in the study did not think the negative perceptions about MXit are that bad because, "it's not like [you're] an alcoholic," implying that there are worse things in society to be considered serious than being addicted to MXit.

Some MXit users have negative perceptions of the people who do not use the system. The users viewed those who do not use MXit as weird, not fond of technology, and social outcasts because "everyone understands that MXit is a simple, cheap and efficient way to chat." Such users could not understand why some people would have negative perceptions of MXit. They perceived the people who are against the use of MXit as "old fashioned", which is why they would perceive a MXit user as "a horrible little kid who chats to strangers on the Internet and does bad things." One respondent called these people "extremists" because they have little knowledge about MXit and therefore hold a one-sided view. Holding negative views of those who are not in the in-group was also reported amongst the users of computer-based instant messaging (Grinter \& Palen, 2002).

All the youth respondents were aware of their parents' concerns vis-à-vis their use of MXit. The MXit users believed that most of these perceptions were greatly influenced by the media. The users also indicated that parents blamed whatever noticeable changes in their children's behaviours on MXit. For instance, one MXit user recalled his mother saying:

'You and this MXit thing ... We're gonna block your contract... We'll break your thumb... You use it too often, that's why your grades went down ... Get off MXit! ... Now, I've heard you can download porn on MXit, is that why you're always on?'

All the youth from our sample indicated that they had had a discussion with their parents about MXit. However, in most cases the discussions were superficial. Most of the respondents did not appreciate the parents' concerns about MXit. One dismissed the conversion as "the usual parents' stuff. " Interestingly though, most of the users opted not to be confrontational about the issue; some indicated that they opted not to use MXit "in the presence of their parents out of respect."

The views about MXit and the people who use it, both the negative aspects as well as the positives, make up the qualities that form the group's overall self-esteem. The negative qualities appear to strongly define the self-esteem of MXit users to the general public. According to Lemish 
and Cohen (2005), commodities may be used by consumers to construct the self as well as one's social identity and social relationships. MXit is, in this regard, the commodity that is used by the youth to construct their social identity. It is interesting, however, that some users hold some negative views of the system and its users - the same group they identify with.

\section{Parents' Perceptions of MXit and Its Users}

All the parents in our sample were concerned about the use of MXit. The concerns ranged from fears that their children "may be talking to serial killers", "they are wasting time", "they are busy with their phones instead of talking to real people." This finding is consistent with the findings of Chigona and Chigona (2008) who showed that parents and educators are concerned about the youth using MXit because it is perceived to be addictive and hinders the youth's concentration on academic work.

Consistent with what the youth respondents said, all the parents in our sample did not have a full understanding of the nature of the system. None of the parents was aware of the differences between one-on-one chatting and chatrooms. The parents were also not aware of the other services offered via MXit; "Andiyazi [I don't know], I just know that the children use it to talk to friends and some weird adults." The parents indicated that their knowledge of MXit was mainly from media reports. This finding is interesting since Chigona and Chigona (2008) noted that the media mainly quotes parents to legitimise horror stories about MXit. This finding could therefore point to the fact that the media and the parents are engaged in circular referencing.

Based on the negative perceptions, some parents did not permit their children to use the system. The following extracts exemplify the concerns of the parents:

I read it from the newspapers that somewhere somehow MXit is not good because you chat with somebody you don't know. What if you're chatting with a serial killer?

I'm not comfortable with this thing ... one boy while on MXit, he [was chatting] with this person for quite a long time and then this person invited to see him in a mall. Ever since I read that story, I'm so scared of MXit.

I didn't even want to buy him a cellphone, but because ... my land line has a problem since last year November, there was a cable theft in Khayelitsha. So now I [couldn't] communicate with him anymore. So [my children] just raised the point that '[since] we don't have phone at home, why don't you allow him to get a cell-phone?' Then my daughter bought him a cellphone so that we can communicate. But I didn't want it, really.

Despite the concerns, all the parents in our sample did not attempt to stop their children from using the system but instead opted to either remain silent or educate their children on "how to avoid the traps out there."

Look, I know I've heard there's now a pool, a slut-pool or something ... um, so I wouldn't worry to ban my child from MXit because of that, .... I'm relying on what I've taught him to be responsible, um, [...] I would imagine, but overall, um, I trust what I've taught him to carry out.

... I trust that his instincts are [pause] better judgement because of what I taught him.

Most parents justified their decision not to ban the use of MXit based on the cost of communication. MXit costs significantly less than most communication channels. The parents allowed their children to use MXit because it saved them (parents) money on airtime for their children. One MXit user respondent said: 
... [my parents] heard the weird stories ... but they know that it's cheap, they know that we communicate with our family and things like that. So they don't really care that we're on MXit.

Some parents also opted not to ban the use of MXit because they considered that policing such a ban would be a challenge, mainly because it was not easy for the parents to monitor what their children were doing all the time.

I don't have any restrictions because I'm here now and sometimes when he asks money to buy the airtime, I just give, I don't ask 'what are you going to do?' Anyway airtime is for calling, so I can't say I'm too strict or I can say he mustn't do it, he can do it, ... He can do it without informing me.

If I ban him from using MXit... I'm not there [with the children] 24 hours a day though. Then he'll start to sneak it in ... so I know when he goes to bed he plays under his blanket with MXit.

In addition to the challenge of policing the children's use of MXit around the clock, the parents also expressed the dilemma that the system was part in an essential gadget - the cellphone. Most parents considered a cellphone a 'must have' for their children since "it makes communication and coordination easier." The challenge then was how a parent can selectively control the use of some of the applications on this essential tool. As one parent said "It is like trying to separate tares from the wheat". ${ }^{\circ}$

All the parents had spoken to their children about MXit. The conversations mostly revolved around care about meeting people online and giving out information. However, one difference that was observed was the nature of the conversations between fathers and mothers with their children. All the four fathers had more general discussions about MXit with their children. The fathers' concerns were general in the sense that they were not just about taking care on MXit but about taking care in life in general. For instance, one father said:

I would remind him about what's available out there ... so I trust that his instincts [would give him] better judgement ... He can sit next to me [while using] MXit, I won't question ... but his mother's more worried than ... I am.

In contrast, the mothers' discussions seemed more specific about MXit. As one mother who was so concerned about her children's use of the system said:

... so I openly discuss MXit with my children that this thing is dangerous ... because now it ends up being 'Can I meet you?' whatever, when they find who they're meeting, it's to their detriment.

It is argued that part of the transition from childhood to adulthood is the changing of "parental tabs" from mandatory to voluntary and it seems MXit can "work at cross purposes with the transition stage where children ... are taking the first full steps towards informational self-sufficiency or unaccountability to parents" (Levinson, 2004: 90, as cited by Bosch, 2008).

\section{Discussion and Conclusion}

The findings show that both the users and the parents of users were aware of the negative discourse surrounding MXit. Some of the users and all the parents held negative views about the use of MXit. It is interesting, however, that the users still continued to use the system and the parents

\footnotetext{
${ }^{1}$ The expression is based on a Biblical parable which shows that it is difficult to separate the good from the bad; therefore it may be safer to let them co-exist (Matthew 13 verses 24-30).
} 
still permitted the use of the system. In some cases, the parents even legitimised the use of the system by "buying airtime" for their children to use for "MXiting"; in some cases the parents asked the children to pass on messages to relatives via MXit. This then brings us to one of the research questions in this pilot study: how do users and parents of users reconcile with negative discourse surrounding MXit? Our findings show that one of the techniques employed by both the users and the parents was self- justification.

Self-justification describes how a person justifies a behaviour which is inconsistent with his/her belief (Holland, Meertens, \& Van-Vugt, 2002). Self-justification is prompted by cognitive dissonance, that is, the feeling one has when the person holds two cognitions which are inconsistent with each other (Festinger, 1957). For example, one may believe that using MXit is wrong and at the same time still use the system. If a person is not considering taking the option of stopping using the system, then the feeling should be addressed using other strategies, otherwise it may negatively affect one's self esteem. There are two types of dissonance: hedonistic and moral dissonance. Hedonistic dissonance is prompted by actions which harm oneself, while moral dissonance is prompted by actions which harm others. There are two self-justification strategies - internal and external self-justification strategies (Holland et al., 2002). Internal self-justification involves changing one's perception of the problem behaviour. These strategies may include change of attitude, trivialisation or denial of the negative consequences of the behaviour. External justification, on the other hand, tends to diminish one's responsibility for behaviour.

We noticed that the users and the parents used different self-justification strategies to deal with their dissonance. The users employed mainly internal self- justification strategies, while the parents employed external self-justification strategies. For instance, the youth trivialised and, in some instances, denied the consequences of using MXit. Some of the youth trivialised the parents' concerns as "the usual parents' stuff"; some indicated that the system was not that bad, it was just the media that made it look bad; others indicated that there are worse things, like substance abuse. Similar strategies were also noted in a study on dysfunctional usage of mobile email (Middleton \& Cukier, 2006). It is also interesting that while admitting the potential of addictiveness of the system, most respondents saw themselves as being in control and only talked about friends who were in that situation. This behaviour, which is called the "third person effect" (Davison, 1983; Lemish \& Cohen 2005; Perloff, 2002), was also noted by Bosch (2008).

The parents mainly employed external self-justification. They claimed that external factors forced them to allow their children to use the system. For instance, the parents indicated that their decision was justified by economic factors; for example, MXit is cheaper than alternative communication channels. Parents also indicated that they were helpless in that they could not police the ban since it was technically impossible to do so (helplessness is one of the external selfjustification strategies). The differences between self-justification strategies employed by the users and by the parents are a result of the differences in the types of dissonance experienced by the two groups. On the one hand, the users experienced hedonistic dissonance and, according to Holland and colleagues (2002), this type of dissonance is mainly dealt with by internal selfjustification. On the other hand, the parents experienced moral dissonance and that is normally dealt with by using external self-justification.

This pilot study has explored the meanings the youth in South Africa attach to MXit and its use, and how they negotiate its use in view of the general negative view from the media and the parents. Like many other SITs, MXit plays a significant role in the youth's social networking. It enables the youth to create and recreate their identities through their connectivity with other people and social groups. The study has shown that MXit users have a positive view about themselves as system users. The users are proud to be users and have a mental perception of the system that allows them to identify themselves with it. It was also noted that the users' perception of the system and of other users, differ from parents' and non-users' perception of the same. The difference in 
perceptions between the parents and the users could be a result of the split between the technologically progressive and the technologically conservative groups - this would need to be explored further.

This study found that MXit has become part of the youth's routines in some way or the other. For some users MXit is ritual as well as instrumental. The system and its use form part of the youths' daily rhythm contributing to their daily lives. Some users in the study expressed a dependency and attachment to the system. Many users are so committed and/or addicted to the system that they spend long hours chatting via MXit. This is one of the reasons many parents cite for disliking their children's use of MXit.

This study posits that both the users and the parents of users deal, to some extent, with cognitive dissonance arising from the negative discourse of MXit and their continued use or support of use of the system. The study further posits that the users and the parents are employing selfjustification strategies to deal with the dissonance. These claims need to be explored further with a larger sample. We acknowledge that our sample was limited in size and that it was biased towards users of MXit and parents with children who use MXit. Young non-users or those who have stopped using the system, as well as parents of children who do not use the application, would offer valuable insights on the use and perceptions of MXit. It would be interesting to investigate the strategies used by parents who have managed to ban the use of MXit.

\section{References}

Bonebrake, K. (2002). College students' internet use, relationship formation, and personality correlates. Cyberpsychology and Behavior, 5(6). Mary Ann Liebert, Inc.

Bosch, T. (2008). Wots ur ASLR? Adolescent girls' use of MXit in Cape Town. Commonwealth Journal of Youth Studies, 6(2).

Buckingham, D. (1993). Children talking television: The making of television literacy. London: The Falmer Press.

Butgereit, L. (2007). Math on MXit: Using MXit as a medium for mathematics education. Meraka INNOVATE Conference for Educators, CSIR, Pretoria, 18-20 April 2007

Chigona, A., \& Chigona, W. (2008). MXit up it up in the media: Media discourse analysis on a mobile instant messaging system, Southern Africa Journal of Information and Communication, 9, 42-57.

Chigona, W., Kamkwenda, G., \& Manjoo, S. (2008). Uses and gratifications of mobile internet among the South African Students. South African Journal of Information Management (SAJIM), 10(3).

Cukier W., Ngwenyama, O., Bauer, R., \& Middleton, C. (2009). A critical analysis of media discourse on information technology: Preliminary results of a proposed method for critical discourse analysis. Information Systems Journal, 19(2), 175-196.

Cohen, L., \& Manion, L. (1994). Research methods in education (4th ed.). London: Routledge Falmer.

Davison, W. P. (1983). The third person effect in communication. Public Opinion Quarterly, 47, 1-15.

Duarando, D., Parker, M., \& de la Harpe, R. (2007). Investigation into the usage of mobile instant messaging in tertiary education. Proceedings of Annual Conference of World Wide Web Application.

Ellemers, N., Kortekaas, P., \& Ouwerkerk, J. W. (1999). Self categorisation, committment to the group and group self esteem as related but distinct aspects of social identity. European Journal of Social Psychology, 29, 371 - 389.

Fairclough, N. (1995). Critical discourse analysis: The critical study of language. New York: Longman Group.

Festinger, L. (1957). A theory of cognitive dissonance. Stanford, CA: Stanford University Press. 
Flanagin, A. (2005). IM online: Instant messaging use among college students. Communication Research Reports, 22(3), 175-187.

Francke E., \& Weideman, M. (2007). South African youth and mobile technology impact: The MXit phenomenon. Proceedings of the $9^{\text {th }}$ Annual conference on World Wide Web Applications. September 2007, Johannesburg.

Furedi, F. (1994). A plague of moral panics. Living Marxism, 73(Nov).

Grinter, R., \& Palen, L. (2002). Instant messaging in teen life. ACM Conference on Computer Supported Cooperative Work, pp. 21- 30.

Hancock, J. T., Thom-Santelli, J., \& Ritchie, T. (2004). Deception and design: The impact of communication technology and lying behaviour. CHI 2004, 6 (1), pp. 129 -134.

Holland, R., Meertens, R., \& van-Vugt, M. (2002). Dissonance on the road: Self esteem as a moderator of internal and external self-justification strategies. Personality and Social Psychology Bulletin, 28(12), $1713-1724$.

Ito, M. (2005). Mobile phones, Japanese youth, and the re-placement of social contact. In R. Ling \& P. E. Pedersen (Eds.), Mobile communications: Re-negotiation of the social sphere (pp. 131-148). Surrey, UK: Springer.

Jensen, K. B., \& Jankowsk, N. (Eds.). (1991). A handbook of qualitative methodologies for mass communication research. London: Routledge.

Johnsen, T. E. (2003). The social context of the mobile phone use of Norwegian teens. In J. E. Katz (Ed.), Machines that become us: The social context of communication technology (pp. 161-170). New Brunswick, NJ: Transaction Publishers.

Kraut, R., Kiesler, S., Boneva, B., Cummings, J., Helgeson, V., \& Crawford, A. (2002). The internet paradox revisited. Journal of Social Issues, 58(1), 49-74.

Lemish, D., \& Cohen, A. (2005). Tell me about your mobile and I'll tell you who you are: Israelis talk about themselves. In R. Ling \& P. E. Pedersen (Eds.), Mobile communications: Re-negotiation of the social sphere (pp. 187-202). Surrey, UK: Springer.

Lull, J. (2000). Media, communication, culture. Cambridge: Polity Press.

McKenna, K. Y. A., Green, A. S., \& Gleason, M. E. J. (2002). Relationship formation on the Internet: What's the big attraction? Journal of Social Issues, 58(1), 9-31.

Middleton, C., \& Cukier, W. (2006). Is mobile email functional or dysfunctional? Two perspectives on mobile email usage. European Journal of Information Systems, 15, 252-260.

Miles, M. B., \& Huberman, A. M. (1994). Qualitative data analysis: An expanded sourcebook. London: SAGE.

Mitrano, T. (2006). A wider world: Youth, privacy, and social networking technologies. EDUCAUSE Review, 41(6), 16-29.

Morley, D., \& Robins, K. (1996). Spaces of identity: Global media, electronic landscapes and cultural boundaries. London: Routledge.

Perloff, R. M. (2002). The third person effect. In J. Bryant \& D. Zillmann (Eds), Media effects: Advances in theory and research (pp. 489-506). Mahwah, NJ: Lawrence Erlbaum.

Petersen, T. (2008). The uses \& gratifications of online social networking in South Africa. Honours Thesis, Department of Information Systems, University of Cape Town.

Riva, G., \& Galimberti, C. (1998). Computer mediated communication: Identity and social interaction in an electronic environment. Genetic, Social and General Psychology Monographs, 124, 434-464. 
Takahashi, T. (2008). Mobile phones and social networking sites: Digital natives' engagement with media in everyday life in Japan. Media, Communication and Humanity 2008, Media@lse Fifth Anniversary Conference.

Valenzuela, S., Park, N., \& Lee, K. F. (2008). Lessons from Facebook: The effect of social network sites on college students' social capital. $9^{\text {th }}$ Symposium on Online Journalism, pp 1-4.

Van Manen, M. (1990). Researching lived experience: Human science for an action sensitive pedagogy. New York: State University of New York Press.

\section{Biographies}

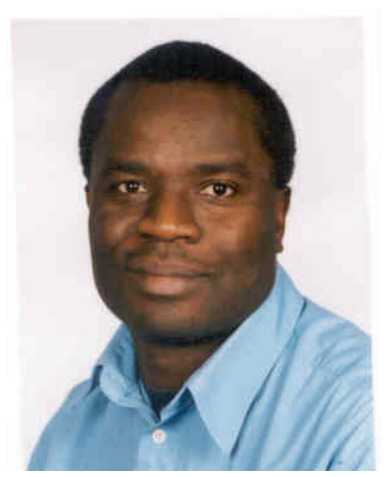

Wallace Chigona, PhD: Wallace is a Senior Lecturer in the Department of Information Systems, University of Cape Town, South Africa. He has previously worked as a Lecturer in Computer Science at the University of Malawi. He obtained his $\mathrm{PhD}$ in Computer Science from the University Of Magdeburg, Germany in 2003. Wallace's research interests include the use ICT for development and the use of mobile technology for development.

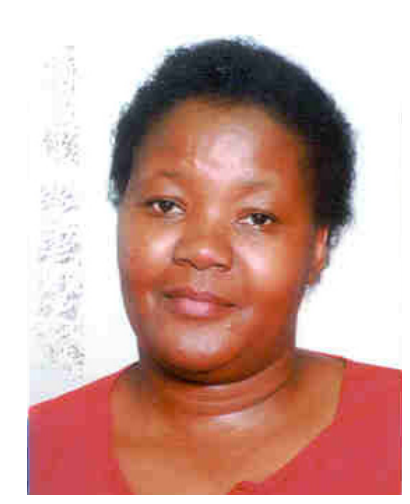

Agnes Chigona, PhD: Agnes is a Post doctoral fellow in the Department of Information Systems, University if Cape Town. Her research focus is on use of ICT in education in disadvantaged areas, and multi cultural education. Agnes received a doctoral of education degree from the Cape Peninsula University of Technology, South Africa in 2008.

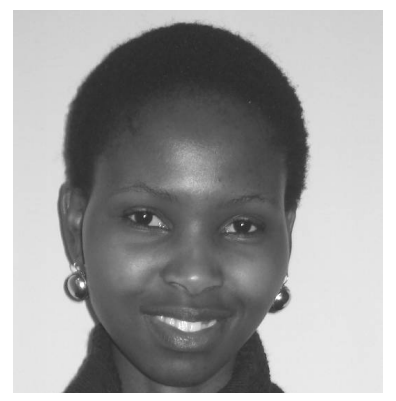

Bomkazi Ngqokelela: Bomkazi has recently graduated from the University of Cape Town, South Africa, with an Honours Degree in Information Systems. Bomkazi is currently working as a Graduate Trainee in the Network Information and Development department of a telecommunications company in Johannesburg, South Africa. 
MXIT: Its Uses, Perceptions and Self-justifications

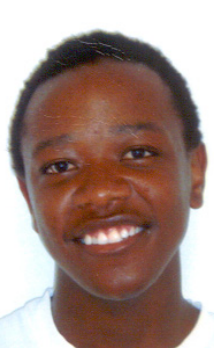

Sicelo Mpofu: Sicelo has recently graduated from the University of Cape Town, South Africa, with an Honours Degree in Information Systems. Sicelo is currently working as a Business Analyst in Cape Town. 